\title{
REPAIR AND STRENGTHENING OF THE WATER PIERS BARRAGES BY INJECTION TECHNIQUE AND ITS EVALUATION
}

\author{
Aly abdel-Zaher Elsayed; Aly Gamal Aly; Mahmoud \\ Hussien Ahmed; and \\ Civil Engineering Department, Faculty of engineering, Assiut University, \\ Assiut, Egypt
}

\section{Omran Abd Elfadil Omran}

Ministry of Water Resources and Irrigation, Sohage, Egypt

(Received May 2, 2011 Accepted November 11, 2011)

The water structures (hydro techniques) dames, reservoirs, barrages ..etc., are complicated engineering structures and may have the demand properties not only hardness and stability but also have the most important property as impermeability [1].

The construction of water structures is highly expensive because they are critical structures and have many purposes. The grand barrages on the Nile are the most important for their many benefits (either in irrigation or industrial ...etc).

Continuous tests are needed to keep them long time working in effective condition with high efficiency in addition, to repair and strengthen every components.

The concrete is the mainly material of the most water structures body and may be subjected to corrosion abrasion and the effect forst may be destroyed by physico-chemical mechanism such as carbonation and phenomena of alkali-aggregate reactions. All of these different modes of deterioration can cause debonding between cement and gravel by the propagation of cracks and loss of material properties [11, 12].

This study concerns with the experimental investigation of injection of barrage body. The main purpose refers to piers completely full of the voids and cracks inside the body material [1], where the cracks are not available to be seen.

The disappeared cracks need special operation to get the main characters to perform the suitable operation, in field by the specific discharge, and grout mixing performance should be known to determine the suitable mixing. In the field which the samples of piers are taken (samples are used in this research), the mixing is from ordinary cement with percentage from bentonite (1-2\%) from cement weight [1]. The diameter of the core samples which be taken from pier body is (38, 44, 48, 52, 64, 76 and $84 \mathrm{mms}$.) and after preparing with ratio between the length to the diameter varied from 1 to 2. A 42 samples from Assiut barrage and 43 samples from Naga-Hammadi barrage were taken to perform the required tests [2, 3, 4]. 
The main objectives of this research are to study the effect of injection to improve the compressive strength and impermeability of the pier body and comparing the results before and after the injection operation [1].

The study concluded that the injection influenced by clear effect on compressive strength. The average compressive strength was increased by $(112.63 \%)$ from the average strength before injection for Assiut barrage and increased by (81.75\%) before injection for Naga-Hammadi barrage. Also the density was improved, to increase the structure solidity and stability.

\section{INTRODUCTION}

This study concentrates on the repair and strengthening of the piers of barrages. Repair, strengthening and retrofitting operations for these structures have to perform for restoration purposes [14].

Different common used techniques for repairing water structures are summarized as follows:

1- Injection: this study scope.

2- Jacketing.

3- Re-arrangement of element.

4- Re- configuration of the structure.

5- Removal\& replacement.

Grouting is a process in which grout in liquid form is pumped into the voids and cracks to fill the fine fissures in concrete and then hardens [3]. The injection operations are very difficult and new operations in the whole world and needs specialists to do.

In the Ministry of Water resources and irrigation, the strengthening of all grand barrages along the Nile is achieved by injection (specially their piers). The records of Assiut [5] and Naga-Hammadi [6] barrages injection operations were used in this study to evaluate the injection technique.

The injection operation was successfully finished and the required results which obtained were analyzed.

\section{EXPERIMENTAL WORK}

The subsequent steps have to be made to give successfully injection operation:

1- Drilling works: Boreholes were made with a suitable diameter to allow the injection mixing to penetrate through the cracks and the fissures. The common diameters of the bore holes are: $(38,44,48,52,64,76$ and $84 \mathrm{mms}$.).

The used drilling operation is rotary system by using water current around the drilling line for cooling, and by using the parallel double core to take out the core samples with sufficient condition to carry out the required tests to be done for the structure member which needs to be repaired. Figure 1 shows the barrage and wood box that the samples were kept in. 


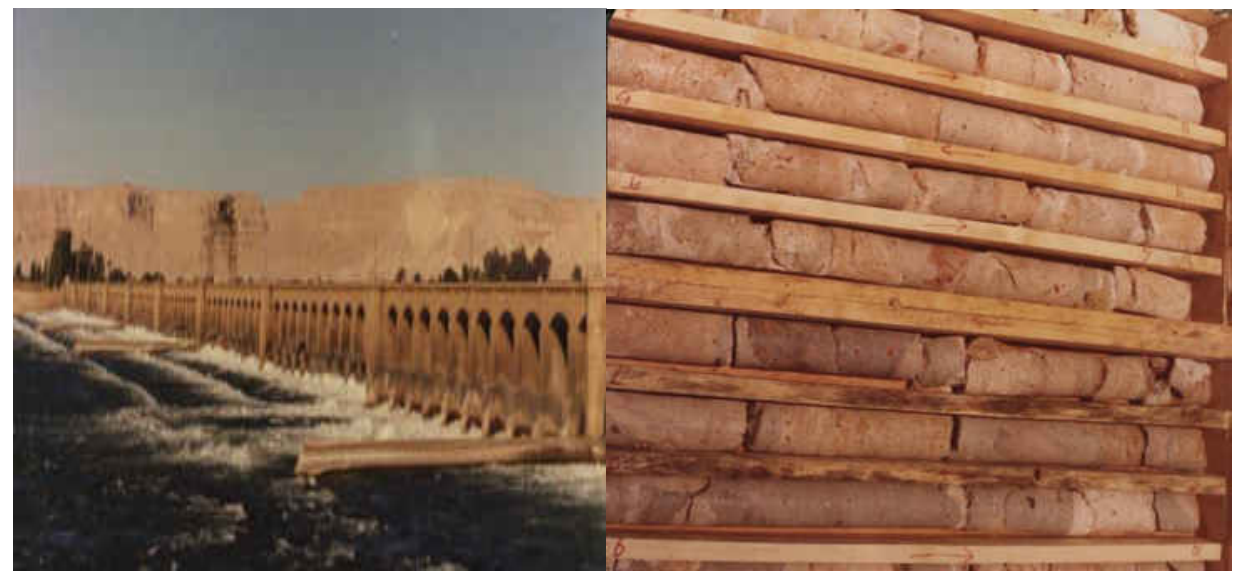

Fig. 1: The barrage and samples.

2- Specific discharge: Specific discharge, the density and consistency of the injection mix are the important operations have to be determined. Permeability test were done after the boreholes reached the total required test and cleaned as follows [1]:

- The borehole depth is divided to intervals as max. $3.00 \mathrm{~m}$ length for one interval to let the discharge is totally effective.-The bottom and the top of interval have to be completely closed to prevent any seepage (make packer) at the up or down of interval Fig. 2, [1].

- The consistency $(\mathrm{C} / \mathrm{W})$ of the injection mixture is determined by using the following formula and Table 1 .

$$
\mathrm{q}=\mathrm{Q} / \mathrm{H} . \mathrm{L}
$$

where: q: specific discharge in $\mathrm{L} / \mathrm{min}$

Q: total discharge in $\mathrm{L} / \mathrm{min}$

$\mathrm{H}$ : pressure in Metric Unit

L: Length of interval in Meter.

Table 1: The mixture consistency

\begin{tabular}{|c|c|}
\hline $\begin{array}{c}\text { Specific discharge } \\
\text { L/ } \mathbf{~ m i n}\end{array}$ & $\begin{array}{c}\text { Cement /Water } \\
\text { C/W }\end{array}$ \\
\hline$<0.1$ & $1: 10$ \\
$0.1: 0.5$ & $1: 5$ \\
$0.5: 1.0$ & $1: 3$ \\
$1.0: 2.0$ & $1: 2$ \\
$2.0: 4.0$ & $1: 1$ \\
$>4.0$ & $1: 0.8$ \\
\hline
\end{tabular}

After testing (specific discharge) and choosing the material of grouting the consistency of injection mixture and the cracks types must be determined exactly as explained in Table 2.

To make control between intervals of injection along the borehole, the packer must be put at the top and the bottom of interval [12], as shown in Fig. 2. 
Table 2: The crack types

\begin{tabular}{|l|l|}
\hline \multicolumn{1}{|c|}{ Crack type } & \multicolumn{1}{|c|}{ Specification } \\
\hline Dormant crack & $\begin{array}{l}\text { Caused by some event in the past and expected to be not } \\
\text { recurred } \\
\text {-e.g. drying shrinkage } \\
\text {-change of loading } \\
\text {-possible settlements }\end{array}$ \\
\hline Active crack & $\begin{array}{l}\text {-it is not constant in width open and close crack e.g. } \\
\text {-Structural loaded } \\
\text {-thermal changes }\end{array}$ \\
\hline Growing crack & $\begin{array}{l}\text {-The original reason for their occurrence persist } \\
\text {-Always increases in width }\end{array}$ \\
\hline Leaking crack & $\begin{array}{l}\text {-Caused by water pressure behind the surface } \\
\text {-Stopped immediately }\end{array}$ \\
\hline
\end{tabular}

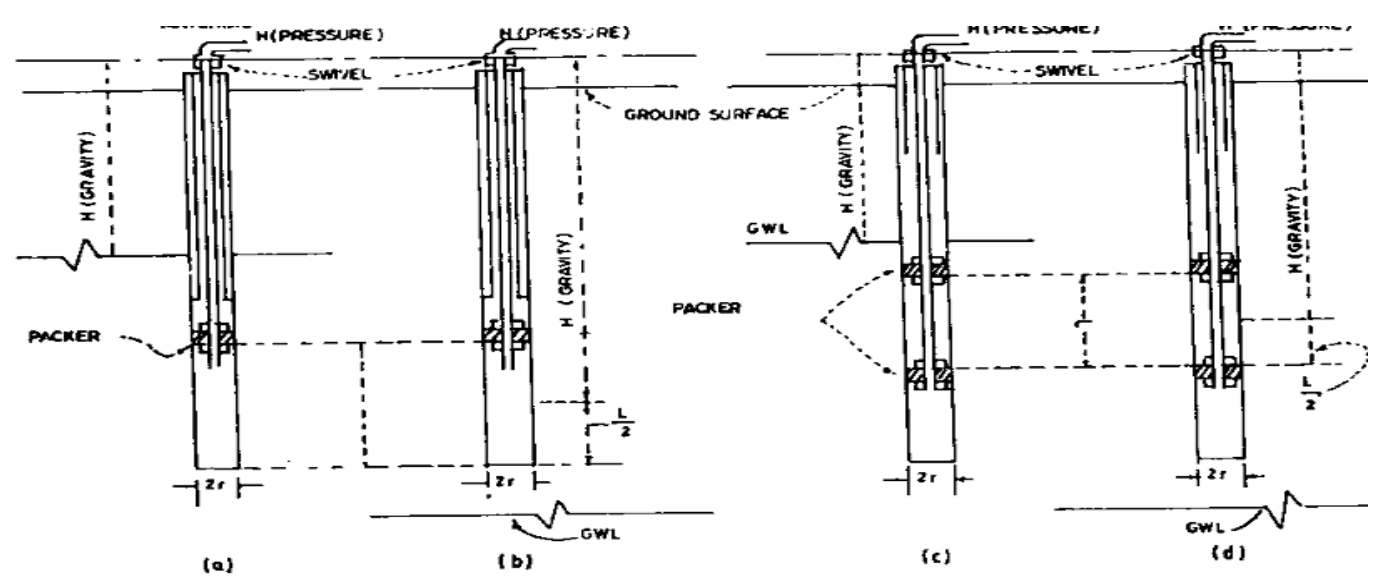

Fig. 2: The packer for borehole intervals.

3-Grouting operation: The grouting line, pump and the mixture with known volume tank should be prepared after the specific discharge and the (W/C) were determined. The using pressure must not exceed (1-2) the pressure around the pier in field [1].

The injection of holes is performed in intervals by specified cement- water fluid under specified pressures. The injection operation was done through the pier's body after drilling special boreholes by pressuring the injection mixture to fill the voids, cracks and joints in the pier body.

The injection operation was done through special pipes (pipe line) carrying the grout from the pump to the working area. These pipes are generally standard black iron pipes of $3.8 \mathrm{~cm}$ diameter. The hose pipe which used to carry the grout was made of a pliable soft rubber to withstand abrasion and the maximum grouting pressures. The rubber hose is used to connect the supply line to the manifold (header) at the hole to facilitate shifting of the grout line from one hole to another [12]. After the permeability test for piers body finished and the consistency (w/c) of the mixture determined (according to that test) have packer installation inside the boreholes to control carry the mixture to the voids and cracks. 
The mixture, which goes through long path in the voids and cracks, depends on many variables. This raft rubber should be soft enough to work under the maximum pressure for grouting. Figure 3 shows the injection system components.

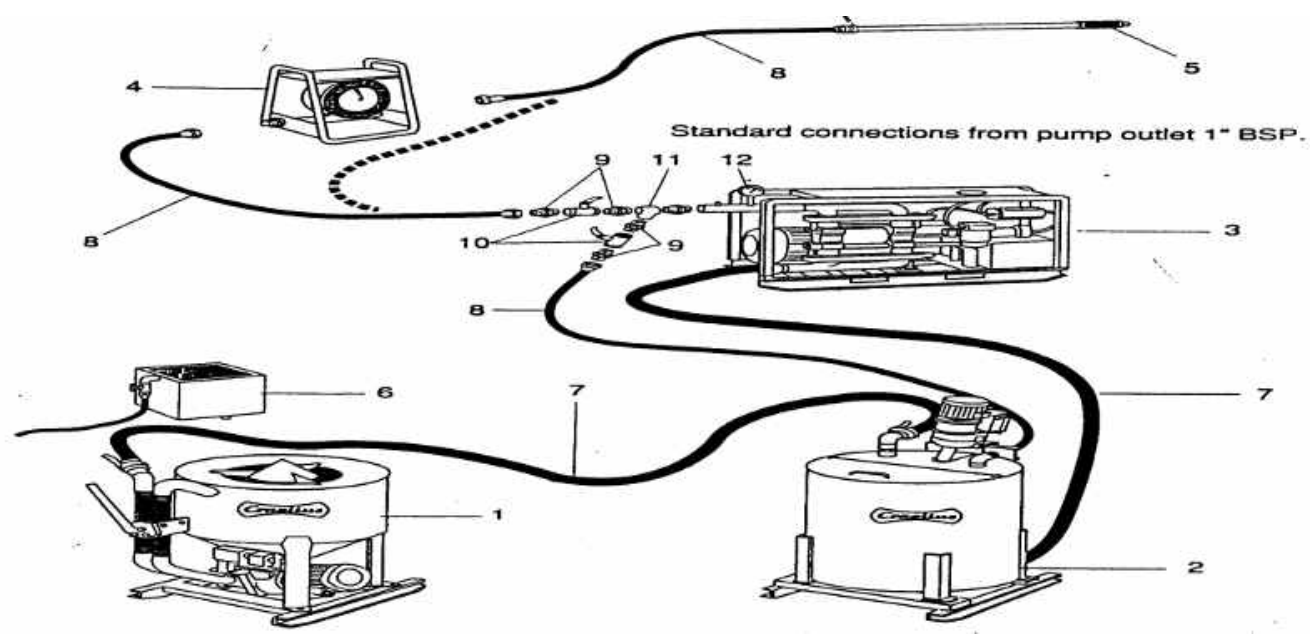

1-Mixer 2-Agitator 3-Pump 4-Recorder 5-Packers 6-Measuring tank 7-Mixer hose 8-Delivery hose 9-Nipple 10-Ball valve 11-T-coupling 12-Presure gauge

Fig. 3: Injection system.

Packer grouting method in which the holes are drilled to full depth and injection in successive increments from the bottom upward has been used this method has been specified for such work [12].

\section{TEST RESULTS AND DISCUSSION}

Results: The results of tests include two parts:

- The first part concentrated on the compressive strength of the samples before and after injection

- The second part concerned the void ratio porosity and density of samples of the two barrages.

The results of the tested samples are as follows:

Compression Test: The compression test was performed by using the 10.00 tons testing machine, for Assiut and Naga-Hammadi barrages samples before and after injection.

- Assiut Barrage

- Before Injection: The results of the compression test which were performed on samples before injection are as shown in Table 3 . 
Table 3: The samples from Assiut barrage before injection.

\begin{tabular}{|c|c|c|c|}
\hline No & Sample & Ultimate load ( kg) & Deformation $\mathbf{\Delta L}(\mathbf{m m})$ \\
\hline 1 & C7-B & 2750 & 0.16 \\
\hline 2 & C15-B & 4000 & 0.13 \\
\hline 3 & C1-A & 3250 & 0.0775 \\
\hline 4 & C9-B & 3480 & 0.075 \\
\hline 5 & C14-B & 3500 & 0.090 \\
\hline 6 & C13-A & 1900 & 0.080 \\
\hline 7 & S21-B & 3500 & 0.1125 \\
\hline 8 & S27-B & 2000 & 0.125 \\
\hline 9 & B1-A & 1250 & 0.105 \\
\hline 10 & B1-B & 1250 & 0.095 \\
\hline 11 & B4-B & 1000 & 0.0675 \\
\hline
\end{tabular}

- After Injection: The results of the compression test which were performed on samples after injection are as shown in Table 4.

Table 4: The samples from Assiut barrage after injection.

\begin{tabular}{|c|c|c|c|}
\hline No. & sample & Ultimate load $\mathbf{( k g )}$ & Deformation $\mathbf{\Delta L}(\mathbf{m m})$ \\
\hline 1 & C7-A & 8250 & 0.155 \\
\hline 2 & C5-B & 7500 & 0.145 \\
\hline 3 & C2-A & 10000 & 0.145 \\
\hline 4 & C14-A & 5200 & 0.135 \\
\hline 5 & C11-B & 7800 & 0.14 \\
\hline 6 & C3-B & 5600 & 0.195 \\
\hline 7 & C30-A & 5230 & 0.1675 \\
\hline 8 & C15-A & 6750 & 0.13 \\
\hline 9 & S1-A & 5250 & 0.21 \\
\hline 10 & S26-A & 5500 & 0.14 \\
\hline 11 & S37-B & 5000 & 0.10 \\
\hline 12 & B7-A & 2000 & 0.0875 \\
\hline 13 & B7-B & 2000 & 0.10 \\
\hline
\end{tabular}

The $(\mathrm{P}-\Delta \mathrm{L})$ curves for the samples before and after injection were plotted in Figs. 4-7, as follows: 
Assuit concrete samples -1

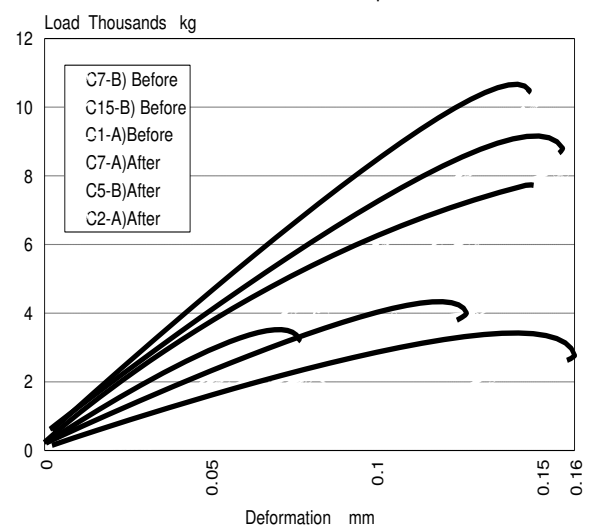

Fig. 4: P- $\Delta \mathrm{L}$ curves for Assiut concrete samples. Assuit barrage (stone samples)

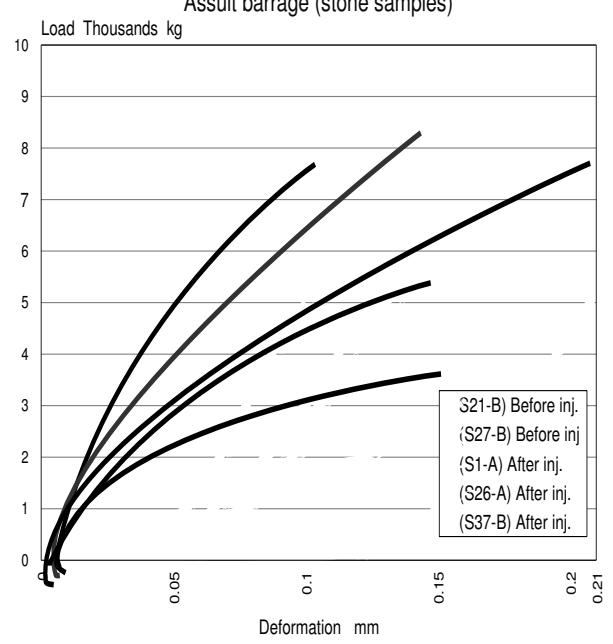

Fig. 6: $\mathrm{P}-\Delta \mathrm{L}$ curves for stone samples.

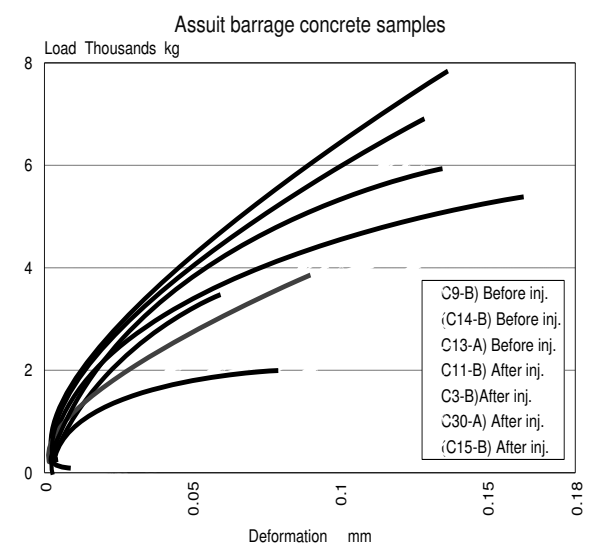

Fig. 5 : P- $\Delta \mathrm{L}$ curves for Assiut barrage concrete samples.

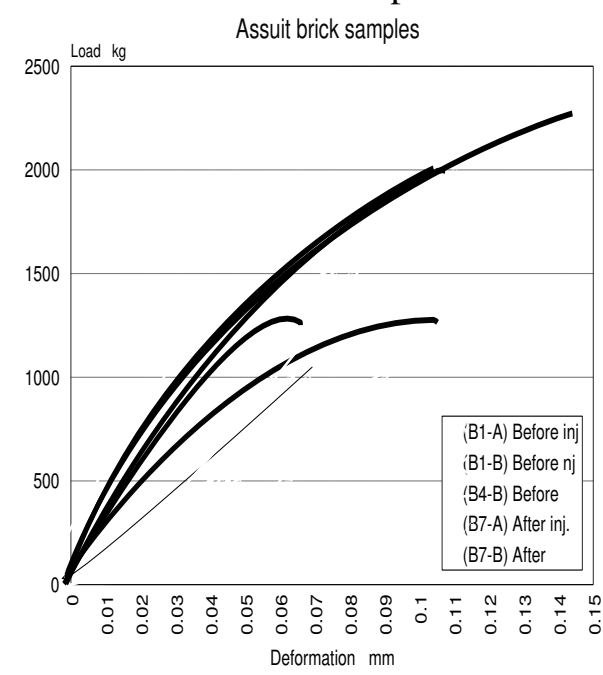

Fig. 7: P- $\Delta \mathrm{L}$ curve for Assiut brick samples.

\section{- Naga-Hammadi Barrage}

Tables 5 and 6 contain the results of compression test which were performed on NagaHammadi barrage samples before and after injection.

\section{- Before Injection}

The results of compression test which performed on samples before injection are shown in Table 5. 
Table 5: Naga-Hammadi barrage samples before injection.

\begin{tabular}{|c|c|r|c|}
\hline No & Sample & Ultimate load $\mathbf{( P u} \mathbf{~ k g}$ & Deformation $\mathbf{\Delta L}(\mathbf{m m})$ \\
\hline 1 & $55-\mathrm{A}$ & 4000 & 0.105 \\
\hline 2 & $23-\mathrm{A}$ & 3750 & 0.080 \\
\hline 3 & $31-\mathrm{A}$ & 4000 & 0.105 \\
\hline 4 & $4-\mathrm{B}$ & 4250 & 0.155 \\
\hline 5 & $19-\mathrm{A}$ & 3500 & 0.1475 \\
\hline 6 & $47-\mathrm{A}$ & 3750 & 0.090 \\
\hline 7 & $53-\mathrm{C}$ & 3250 & 0.0925 \\
\hline 8 & $21-\mathrm{B}$ & 4250 & 0.090 \\
\hline
\end{tabular}

\section{- After injection:}

The results of the compression test which were performed on samples after injection are shown in Table (6).

Table 6: Naga-Hammadi samples after injection.

\begin{tabular}{|c|c|c|c|}
\hline No & Sample & Ultimate load $\mathbf{( P u ) k g}$ & Deformation $\mathbf{\Delta L ( m m )}$ \\
\hline 1 & $2-B$ & 9250 & 0.170 \\
\hline 2 & $3-A$ & 7000 & 0.125 \\
\hline 3 & $5-B$ & 6750 & 0.110 \\
\hline 4 & $6-A$ & 8750 & 0.135 \\
\hline 5 & $8-B$ & 5250 & 0.110 \\
\hline 6 & $11-B$ & 6000 & 0.140 \\
\hline 7 & $14-\mathrm{A}$ & 7500 & 0.200 \\
\hline 8 & $15-\mathrm{B}$ & 5500 & 0.0725 \\
\hline 9 & $16-\mathrm{C}$ & 6000 & 0.085 \\
\hline 10 & $20-\mathrm{A}$ & 7500 & 0.150 \\
\hline 11 & $28-\mathrm{B}$ & 5000 & 0.135 \\
\hline 12 & $31-\mathrm{D}$ & 5500 & 0.1125 \\
\hline 13 & $35-\mathrm{C}$ & 9250 & 0.1325 \\
\hline 14 & $37-\mathrm{C}$ & 7000 & 0.145 \\
\hline 15 & $43-\mathrm{C}$ & 9250 & 0.135 \\
\hline 16 & $54-\mathrm{B}$ & 8000 & 0.115 \\
\hline 17 & $59-\mathrm{A}$ & 5250 & 0.175 \\
\hline
\end{tabular}

Load- deformation (P- $\Delta \mathrm{L})$ curves for the samples are given in Figs. 8-11, as follows. 
Naga-Hammadi barrage samples

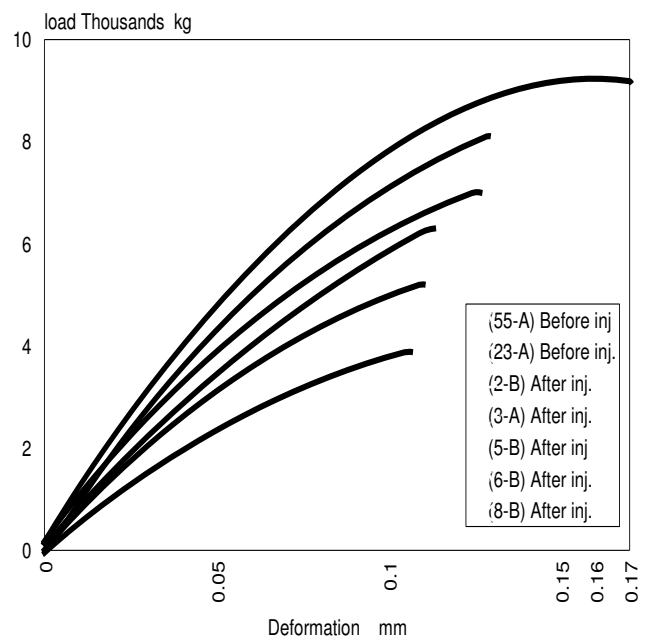

Fig. 8: P- $\Delta \mathrm{L}$ curves for Naga-Hammadi samples.

Naga-Hammadi barrage-3

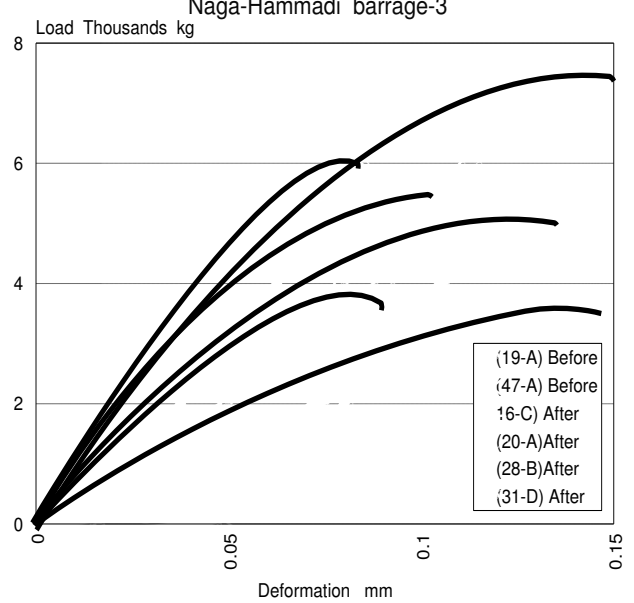

Fig.10: P- $\Delta$ L curves for Naga-Hammadi barrage.
Naga-Hammadi barrage samples.

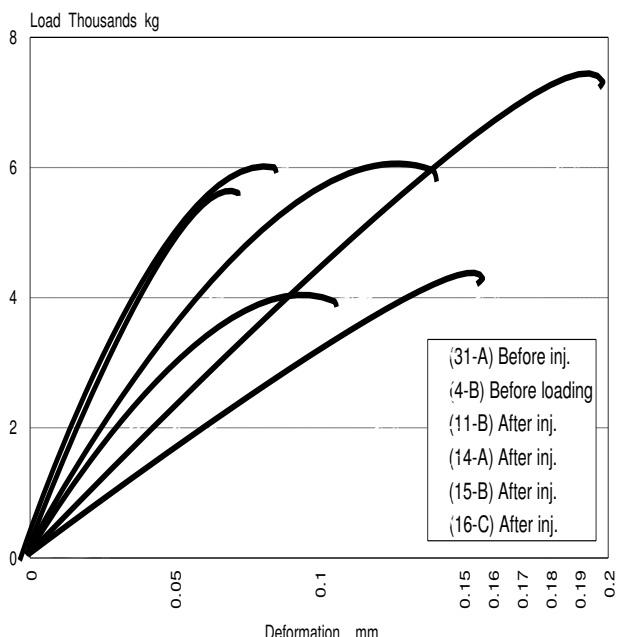

Fig. 9: P- $\Delta \mathrm{L}$ curves for Naga-Hammadi samples.

Naga-Hammadi barrage samples -4

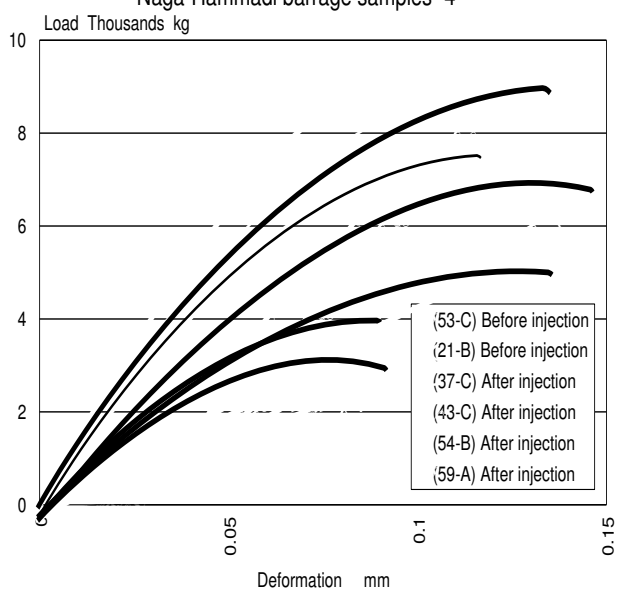

Fig. 11: P- $\Delta$ L curves for Naga-Hammadi barrage samples.

\section{DISCUSSION}

\section{Compression Test:}

\section{- Assiut barrage}

- Before injection: The results of compression test for the samples from Assuit barrage are given in Table 7 . 
Table 7: The samples from Assiut barrage before injection.

\begin{tabular}{|c|c|c|c|c|c|}
\hline No & Sample & $(\mathrm{Su}) B\left(\mathrm{~kg} / \mathrm{cm}^{2}\right)$ & $\left(\mathrm{Su}^{\prime}\right) B\left(\mathrm{~kg} / \mathrm{cm}^{2}\right)$ & $\zeta=(\Delta \mathrm{L} / \mathrm{H})$ & Remarks \\
\hline 1 & C7-B & 140.3 & \multirow{6}{*}{$\left(\mathrm{Su}^{\prime}\right) \mathrm{B}=168.7$} & 0.0022 & \multirow{11}{*}{ 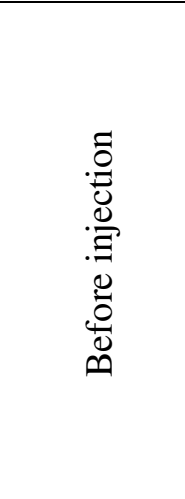 } \\
\hline 2 & C15-B & 253.5 & & 0.0018 & \\
\hline 3 & C1-A & 165.6 & & 0.0011 & \\
\hline 4 & C9-B & 177.55 & & 0.0011 & \\
\hline 5 & C14-B & 178.3 & & 0.00125 & \\
\hline 6 & C13-A & 96.94 & & 0.0011 & \\
\hline 7 & S21-B & 178.30 & \multirow{2}{*}{$\left(\mathrm{Su}^{\prime}\right) \mathrm{B}=140.1$} & 0.0011 & \\
\hline 8 & S27-B & 101.90 & & 0.0014 & \\
\hline 9 & B1-A & 63.78 & \multirow{3}{*}{$\left(\mathrm{Su}^{\prime}\right) \mathrm{B}=59.53$} & 0.0014 & \\
\hline 10 & B1-B & 63.78 & & 0.0013 & \\
\hline 11 & B4-B & 51.02 & & 0.0009 & \\
\hline
\end{tabular}

- After injection: The results of compression test for the samples from Assiut barrage are given in Table (8).

Table 8: The samples from Assiut barrage after injection.

\begin{tabular}{|c|c|c|c|c|c|}
\hline No & Sample & $\begin{array}{ll}(\mathrm{Su}) \mathrm{A} & \left(\mathrm{kg} / \mathrm{cm}^{2}\right)\end{array}$ & $\left(\mathrm{Su}^{\prime}\right) \mathrm{A}\left(\mathrm{kg} / \mathrm{cm}^{2}\right)$ & $\zeta=(\Delta \mathrm{L} / \mathrm{H})$ & Remarks \\
\hline 1 & C7-A & 420.4 & \multirow{8}{*}{358.71} & 0.0022 & \multirow{13}{*}{ 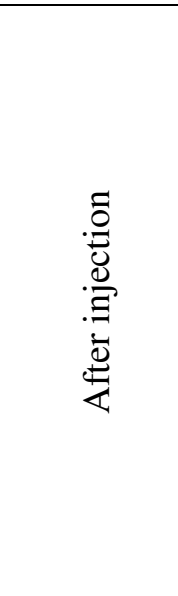 } \\
\hline 2 & C5-A & 382.2 & & 0.0020 & \\
\hline 3 & C2-A & 509.6 & & 0.0020 & \\
\hline 4 & C14-A & 265.31 & & 0.0019 & \\
\hline 5 & C11-B & 397.96 & & 0.00194 & \\
\hline 6 & C3-B & 285.72 & & 0.0027 & \\
\hline 7 & C30-A & 265.56 & & 0.0023 & \\
\hline 8 & C15-A & 342.9 & & 0.0018 & \\
\hline 9 & S1-A & 267.45 & \multirow{3}{*}{267.63} & 0.0029 & \\
\hline 10 & S26-A & 280.33 & & 0.0019 & \\
\hline 11 & S37-B & 255.10 & & 0.0014 & \\
\hline 12 & B7-A & 114.3 & \multirow{2}{*}{108.11} & 0.0019 & \\
\hline 13 & B7-B & 10152 & & 0.0014 & \\
\hline
\end{tabular}

The ultimate strength $(\mathrm{Su})$ and the average ultimate strength $\left(\mathrm{Su}^{\prime}\right)$ for the samples are given in Fig. 12.

The analysis and calculations for the results can be made as follows:

\section{Concrete samples:}

a-The average ultimate strength for the samples before injection $\left(\mathbf{S u}^{\prime}\right) \mathbf{B}=\mathbf{1 6 8 . 7} \mathrm{kg} / \mathrm{cm}^{2}$. b-The average ultimate strength for the samples after injection $\left(\mathbf{S u}^{\prime}\right) \mathbf{A}=\mathbf{3 5 8 . 7 1} \mathrm{kg} / \mathrm{cm}^{2}$ with increase of $(\underline{\mathbf{1 1 2 . 6 3} \%)}$ compared with the average ultimate strength before injection $\left(\mathrm{Su}^{\prime}\right) \mathrm{B}$. 


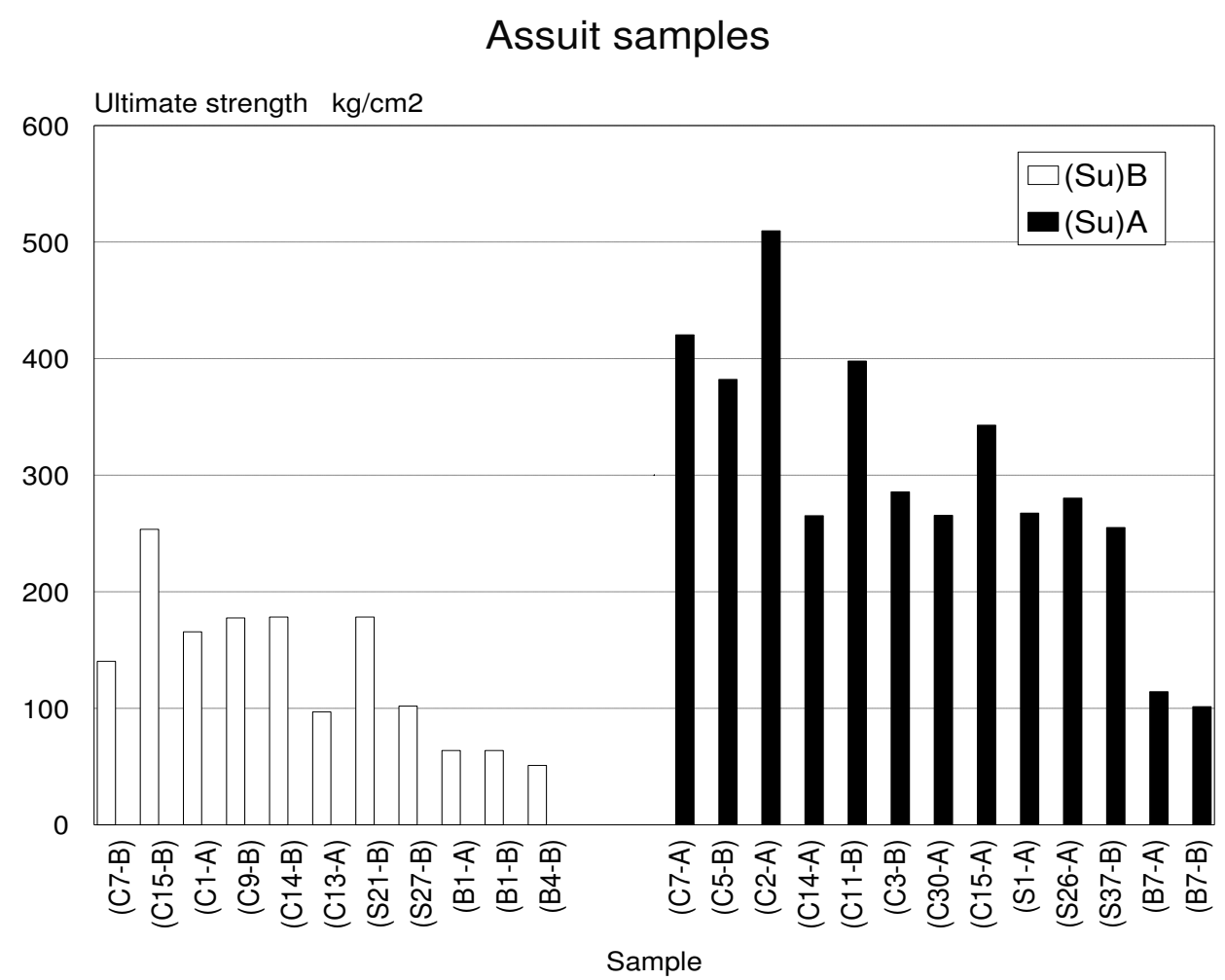

Fig. 12: The ultimate strengths for Assiut barrage samples (before and after) injection.

\section{Stone samples:}

a-The average ultimate strength for the samples before injection $\left(\mathbf{S u}^{\prime}\right) \mathbf{B}=\mathbf{1 4 0 . 1} \mathrm{kg} / \mathrm{cm}^{2}$ b-The average ultimate strength for the samples after injection $\left(\mathbf{S u}^{\prime}\right) \mathbf{A}=\mathbf{2 6 7 . 6 3} \mathrm{kg} / \mathrm{cm}^{2}$ with increase of $(\mathbf{9 1 . 0 3 \%})$ compared with the average ultimate strength for the samples before injection $\left(\mathrm{Su}^{\prime}\right) \mathrm{B}$.

\section{Brick samples :}

a-The average ultimate strength for the samples before injection $\left(\mathbf{S u}^{\prime}\right) \mathbf{B}=\mathbf{5 9 . 5 3} \mathrm{kg} / \mathrm{cm}^{2}$ b-The average ultimate strength for the samples after injection $\left(\mathbf{S u}^{\prime}\right) \mathbf{A}=\mathbf{1 0 8 . 1 1} \mathrm{kg} / \mathrm{cm}^{2}$ with increase of $\mathbf{( 8 1 . 2 6 \% )}$ compared with the average ultimate strength for samples before injection $\left(\mathrm{Su}^{\prime}\right) \mathrm{B}$.

\section{-Naga-Hammadi Barrage}

The ultimate strength $(\mathrm{Su})$ and relative strain $\{\zeta=(\Delta \mathrm{L} / \mathrm{H})\}$ for the samples from NagaHammadi barrage are as follows:

-Before injection: The results of compression test for Naga-Hammadi barrage piers samples before injection are given in Table 9. 
Table 9: The samples from Naga-Hammadi barrage before injection.

\begin{tabular}{|c|c|c|c|c|c|}
\hline No. & Sample & $\begin{array}{l}\text { Ultimate strength } \\
(\mathrm{Su}) \mathrm{B} \mathrm{kg} / \mathrm{cm}^{2}\end{array}$ & $\begin{array}{c}\text { Average ultimate } \\
\text { strength }\left(\mathrm{Su}^{\prime}\right) \mathrm{B} \mathrm{kg} / \mathrm{cm}^{2}\end{array}$ & $\zeta=(\Delta \mathrm{L} / \mathrm{H})$ & Remarks \\
\hline 1 & $55-\mathrm{A}$ & 203.8 & \multirow{8}{*}{$\left(\mathrm{Su}^{\prime}\right) \mathrm{B}=195.86$} & 0.0014 & \multirow{8}{*}{ 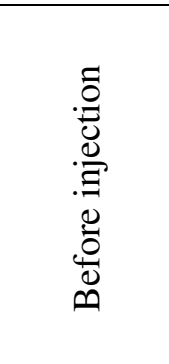 } \\
\hline 2 & $23-\mathrm{A}$ & 191.1 & & 0.0011 & \\
\hline 3 & $31-\mathrm{A}$ & 203.8 & & 0.0014 & \\
\hline 4 & $4-B$ & 216.6 & & 0.0021 & \\
\hline 5 & $19-\mathrm{A}$ & 178.3 & & 0.0020 & \\
\hline 6 & $47-\mathrm{A}$ & 191.1 & & 0.0012 & \\
\hline 7 & $53-\mathrm{C}$ & 165.6 & & 0.0012 & \\
\hline 8 & $21-B$ & 216.6 & & 0.0012 & \\
\hline
\end{tabular}

-After injection: The results of compression test for Naga-Hammadi barrage piers samples after injection are given in Table 10.

Table 10: The samples from Naga-Hammadi barrage after injection.

\begin{tabular}{|c|c|c|c|c|c|}
\hline No. & Sample & $\begin{array}{l}\text { Ultimate strength } \\
(\mathrm{Su}) \mathrm{A}\left(\mathrm{kg} / \mathrm{cm}^{2}\right)\end{array}$ & $\begin{array}{c}\text { Average ultimate } \\
\text { strength }\left(\mathrm{Su}^{\prime}\right) \mathrm{A} \mathrm{kg/ \textrm {cm } ^ { 2 }}\end{array}$ & $\begin{array}{c}\zeta= \\
(\Delta \mathbf{L} / \mathbf{H})\end{array}$ & Remarks \\
\hline 1 & $2-B$ & 471.3 & \multirow{17}{*}{$\left(\mathrm{Su}^{\prime}\right) \mathrm{A}=355.97$} & 0.0023 & \multirow{17}{*}{ 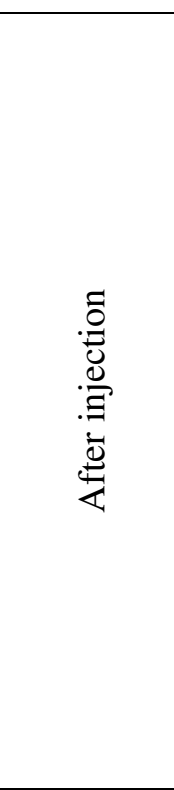 } \\
\hline 2 & $3-A$ & 356.7 & & 0.0017 & \\
\hline 3 & $5-B$ & 344.0 & & 0.0023 & \\
\hline 4 & $6-A$ & 445.9 & & 0.0018 & \\
\hline 5 & $8-\mathrm{B}$ & 267.6 & & 0.0015 & \\
\hline 6 & $11-\mathrm{B}$ & 305.7 & & 0.0019 & \\
\hline 7 & $14-\mathrm{A}$ & 382.2 & & 0.0027 & \\
\hline 8 & $15-\mathrm{B}$ & 280.2 & & 0.0010 & \\
\hline 9 & $16-\mathrm{C}$ & 305.7 & & 0.0011 & \\
\hline 10 & $20-\mathrm{A}$ & 382.2 & & 0.0020 & \\
\hline 11 & $28-B$ & 255.0 & & 0.0018 & \\
\hline 12 & $31-D$ & 280.6 & & 0.0015 & \\
\hline 13 & $35-\mathrm{C}$ & 471.3 & & 0.0021 & \\
\hline 14 & $37-C$ & 356.7 & & 0.0019 & \\
\hline 15 & $43-\mathrm{C}$ & 471.3 & & 0.0018 & \\
\hline 16 & $54-\mathrm{B}$ & 407.6 & & 0.0015 & \\
\hline 17 & $59-\mathrm{A}$ & 267.5 & & 0.0018 & \\
\hline
\end{tabular}

The ultimate strength $(\mathrm{Su})$ and the average ultimate strength $\left(\mathrm{Su}^{\prime}\right)$ for the samples are given in Fig. 13. 


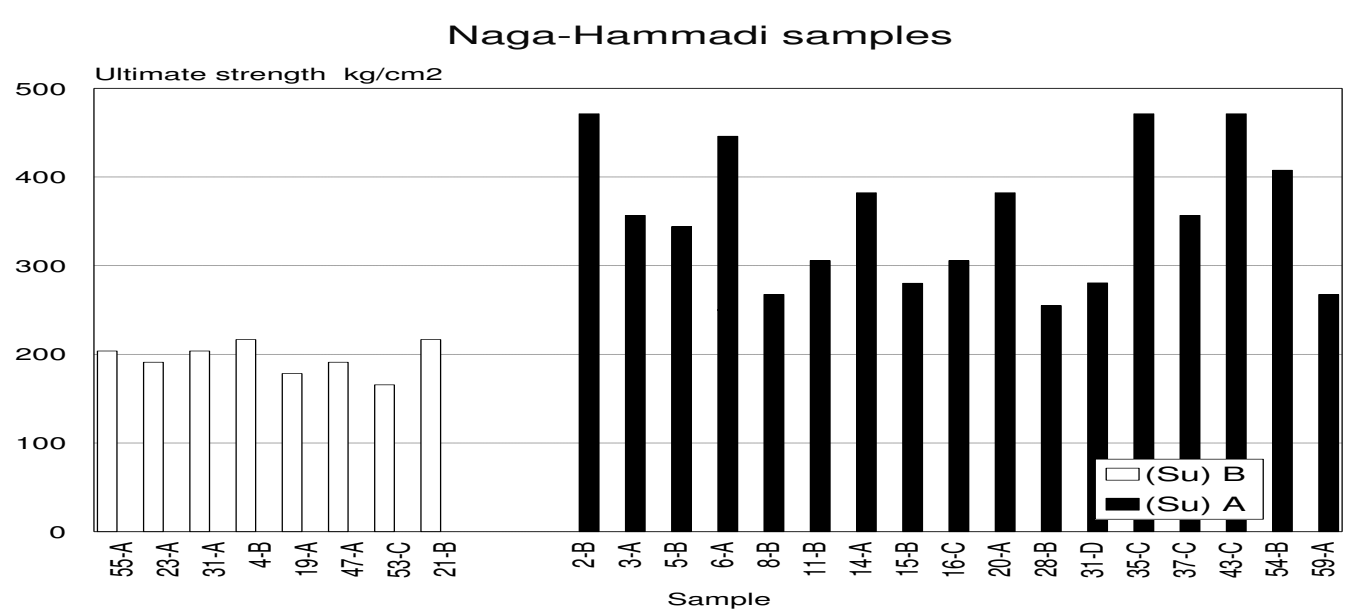

Fig. 13: The ultimate strengths for the Naga-Hammadi barrage samples before and after injection.

The calculations indicate the followings:

a-The average ultimate strength for the samples before injection $(\mathbf{S u}) \mathbf{B}=\mathbf{1 9 5 . 8 6} \mathrm{kg} / \mathrm{cm}^{2}$ b-The average ultimate strength for the samples after injection $\left.\mathbf{S u}^{\prime}\right) \mathbf{A}=355.97 \mathrm{~kg} / \mathrm{cm}^{2}$ with increase (of $(\mathbf{8 1 . 7 5 \%}$ ) compared with the average ultimate strength for the samples before injection $\left(\mathrm{Su}^{\prime}\right) \mathrm{B}$.

\section{- Porosity (n) Void ratio(e), \& Density $(\gamma)$}

The porosity(n) void ratio(e), and $\operatorname{density}(\gamma)$ which were obtained for the samples of the barrages piers are discussed as follows:.

-Assuit Barrage: The samples of Assiut barrage results are given in Table 11 before injection and Table 12 after injection samples.

-Before injection: The calculations of the porosity, void ratio and density for the samples of Assiut barrage before injection are given in Table 11.

Table 11: The samples from Assiut barrage before Injection.

\begin{tabular}{|c|c|c|c|c|c|c|c|c|c|c|}
\hline No. & Sample & $\begin{array}{c}\mathbf{H} \\
\mathbf{m m}\end{array}$ & $\begin{array}{c}\text { D } \\
\text { mm }\end{array}$ & $\begin{array}{l}\text { Vt. } \\
\mathrm{Cm}^{3}\end{array}$ & $\begin{array}{c}\text { Dry wt } \\
\text { gm }\end{array}$ & $\begin{array}{c}\text { Wet } \\
\text { wt gm }\end{array}$ & $\begin{array}{l}\text { Vv. } \\
\text { cm }^{3}\end{array}$ & $\mathbf{n}$ & $\mathbf{e}$ & $\begin{array}{c}(\gamma) \\
\mathrm{gm} / \mathrm{cm}^{3}\end{array}$ \\
\hline 1 & $\mathrm{C} 15-\mathrm{B}$ & 72 & 50 & 147.2 & 349.6 & 372.4 & 22.8 & 0.155 & 0.183 & 2.37 \\
\hline 2 & C5-B & 73 & 50 & 143.3 & 328.1 & 351.3 & 23.2 & 0.162 & 0.193 & 2.29 \\
\hline 3 & $\mathrm{C} 3-\mathrm{A}$ & 72 & 50 & 141.2 & 282.4 & 406.4 & 24.0 & 0.169 & 0.205 & 2.31 \\
\hline 4 & C9-A & 72 & 50 & 141.2 & 317 & 340.7 & 23.7 & 0.168 & 0.202 & 2.24 \\
\hline \multicolumn{8}{|c|}{ The average porosity $\left(\mathrm{n}^{\prime}\right)$, void ratio $\left(\mathrm{e}^{\prime}\right)$ and $\operatorname{density}\left(\gamma^{\prime}\right),(1)$} & .1635 & 0.1958 & 2.3025 \\
\hline 5 & S34-A & 72 & 50 & 141.3 & 281.3 & 303 & 21.7 & 0.154 & 0.182 & 1.99 \\
\hline 6 & S48-A & 73 & 50 & 141.3 & 292 & 313.2 & 21.2 & 0.148 & 0.166 & 2.04 \\
\hline 7 & S1-A & 73 & 50 & 143.3 & 336 & 351.4 & 15.1 & 0.105 & 0.117 & 2.35 \\
\hline 8 & S21-B & 76 & 50 & 149.1 & 348.7 & 380 & 31.3 & 0.21 & 0.266 & 2.34 \\
\hline 9 & S7-A & 73 & 50 & 143.3 & 229.7 & 227.8 & 48.1 & 0.336 & 0.506 & 1.6 \\
\hline \multicolumn{8}{|c|}{ id ratio(e $\left.\mathrm{e}^{\prime}\right)$ and der } & .1906 & .2474 & 2.064 \\
\hline
\end{tabular}


After injection: The porosity, void ratio and density for the samples of Assiut barrage after injection are given in Table 12.

Table 12: The samples from Assiut barrage after Injection.

\begin{tabular}{|c|c|c|c|c|c|c|c|c|c|c|}
\hline No. & Sample & $\begin{array}{c}\mathbf{H} \\
\mathbf{m m}\end{array}$ & $\begin{array}{c}\text { D } \\
\mathbf{m m}\end{array}$ & $\begin{array}{l}\text { Vt. } \\
\mathrm{Cm}^{3}\end{array}$ & $\begin{array}{c}\text { Dry } \\
\text { wt gm }\end{array}$ & $\begin{array}{c}\text { Wet } \\
\text { wt gm }\end{array}$ & $\begin{array}{l}\text { Vv. } \\
\text { cm }^{3}\end{array}$ & $\mathbf{n}$ & e & $\begin{array}{c}(\gamma) \\
\mathrm{gm} / \mathrm{cm}^{3}\end{array}$ \\
\hline 1 & C4-A & 72 & 50 & 141.2 & 336.3 & 337.9 & 1.6 & .01 & 0.011 & 2.38 \\
\hline 2 & C17-A & 72 & 50 & 141.2 & 366.4 & 380.1 & 13.7 & .09 & 0.107 & 2.59 \\
\hline 3 & C1-A & 72 & 50 & 141.2 & 371.8 & 382.7 & 10.9 & .08 & 0.083 & 2.63 \\
\hline 4 & C15-A & 72 & 50 & 141.2 & 353.1 & 362.9 & 9.8 & .07 & 0.074 & 2.5 \\
\hline 5 & C6-B & 72 & 50 & 141.2 & 345.5 & 358.9 & 13.4 & .09 & 0.105 & 2.45 \\
\hline 6 & C10-B & 73 & 50 & 141.3 & 345.9 & 362.9 & 17 & .12 & 0.136 & 2.41 \\
\hline \multicolumn{8}{|c|}{ The average porosity $\left(\mathrm{n}^{\prime}\right)$, void ratio $\left(\mathrm{e}^{\prime}\right)$ and $\operatorname{density}\left(\gamma^{\prime}\right),(2)$} & .09 & 0.086 & 2.49 \\
\hline 7 & S11-B & 73 & 50 & 141.3 & 415.7 & 416.5 & .8 & .01 & 0.142 & 2.9 \\
\hline 8 & S26-A & 72 & 50 & 141.2 & 378 & 382.9 & 4.9 & .035 & 0.036 & 2.68 \\
\hline 9 & S18-D & 72 & 50 & 141.2 & 408.7 & 409.8 & 1.1 & .01 & 0.008 & 2.89 \\
\hline \multicolumn{8}{|c|}{ The average porosity $\left(\mathrm{n}^{\prime}\right)$, void ratio $\left(\mathrm{e}^{\prime}\right)$ and $\operatorname{density}\left(\gamma^{\prime}\right),(2)$} & .02 & .062 & 2.82 \\
\hline
\end{tabular}

Where: Vt: sample total volume

$$
\begin{aligned}
& \mathrm{Vv}: \text { volume of voids } \\
& \mathrm{n}: \text { porosity }=\mathrm{Vv} / \mathrm{Vt} \\
& \mathrm{e}: \text { void ratio=n/(1-n) }
\end{aligned}
$$

Wet weight (wet wt): the submerged weight of the sample

Dry weight: (dry wt): the dry weight of the sample

Density $(\gamma)$ : the density of the sample $=$ dry wt $/ \mathrm{Vt}$

The porosity, void ratio and density before injection and after injection for the samples are given in Figs. 14 and 15.

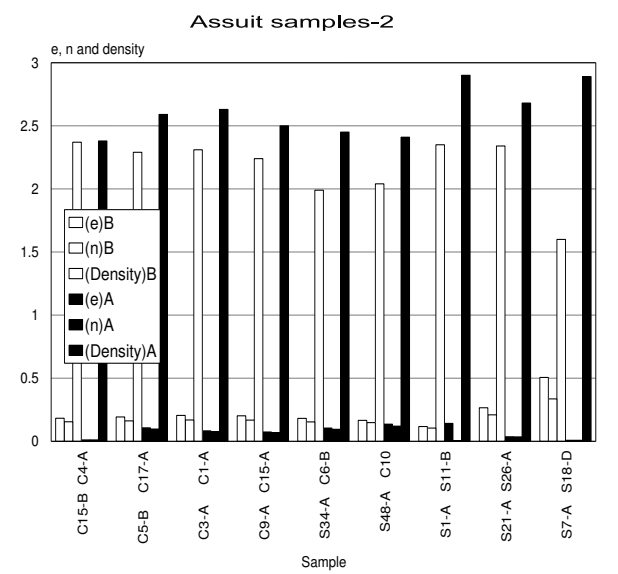

Fig. 14:(n, e and density ) for Assiut Barrage samples.

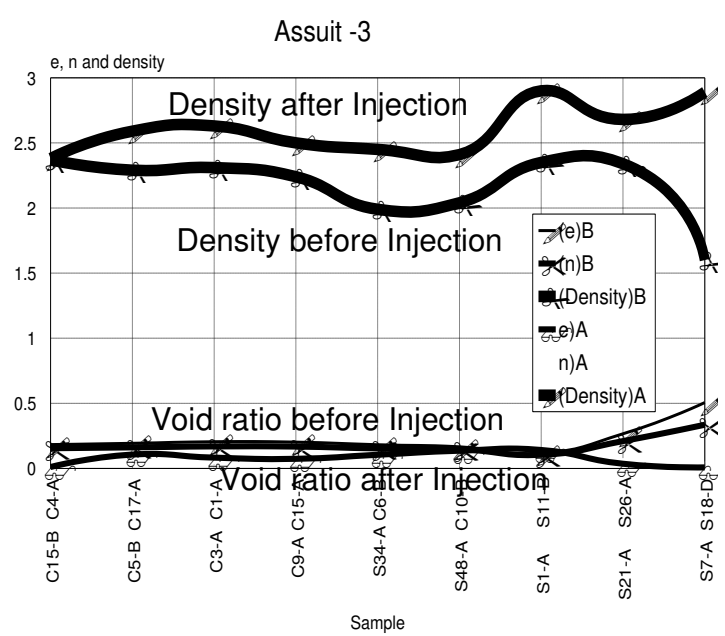

Fig. 15: (n, e and density) before and after injection for Assiut samples. 
The results for Assiut barrage from the previous tables are as follows:

\section{Concrete samples :}

The average void ratio for the samples after injection $\left(\left(\mathrm{e}^{\prime}\right) \mathrm{A}=0.086\right)$ was improved compared with the void ratio for samples before injection \{the average void ratio before injection $\left(\mathrm{e}^{\prime}\right) \mathrm{B}=0.195$ \}

The average porosity for the samples after injection $\left\{\left(\mathrm{n}^{\prime}\right) \mathrm{A}=0.095\right\}$ was improved compared with the porosity for the samples before injection \{the average porosity before injection $\left.\left(\mathrm{n}^{\prime}\right) \mathrm{B}=0.1635\right\}$.

The average density for the samples after injection $\left\{\left(\gamma^{\prime}\right) \mathrm{A}=2.49 \mathrm{gm} / \mathrm{cm}^{3}\right\}$ was improved compared with the density for the samples before injection \{the average density before injection $\left\{\left(\gamma^{\prime}\right) \mathrm{B}=2.3025 \mathrm{gm} / \mathrm{cm}^{3}\right\}$

\section{Stone samples:}

The improvement $\left(\mathrm{e}^{\prime}\right)\left(\mathrm{n}^{\prime}\right)\left(\gamma^{\prime}\right)$ was $(56 \%),(42 \%)$ and $(8.1 \%)$ respectively.

The average void ratio for the samples after injection $\left\{\left(\mathrm{e}^{\prime}\right) \mathrm{A}=0.062\right\}$ was improved compared with the void ratio for the samples before injection \{the average void ratio before injection $\left\{\left(\mathrm{e}^{\prime}\right) \mathrm{B}=0.2474\right\}$.

The average porosity for the samples after injection $\left\{\left(\mathrm{n}^{\prime}\right) \mathrm{A}=0.016\right\}$ was improved compared with the average porosity for the samples before injection $\{$ the average porosity before injection $\left\{\left(\mathrm{n}^{\prime}\right) \mathrm{B}=0.1906\right\}$.

The average density for the samples after injection $\left.\left(\gamma^{\prime}\right) \mathrm{A}=2.82 \mathrm{gm} / \mathrm{cm}^{3}\right\}$ was improved compared with the average density for the samples before injection $\{$ the average density before injection $\left\{\left(\gamma^{\prime}\right) \mathrm{B}=2.06 \mathrm{gm} / \mathrm{cm}^{3}\right\}$

The improvement $\left(\mathrm{e}^{\prime}\right),\left(\mathrm{n}^{\prime}\right),\left(\gamma^{\prime}\right)$ was $(74.9 \%),(67 \%)$ and $(37 \%)$ respectively.

\section{- Naga-Hammadi barrage:}

The void ratio, porosity and density for the samples of Naga-Hammadi barrage are given in Table 14 before injection and Table 15 after injection.

-Before injection: The void ratio, porosity and density for the samples of NagaHammadi barrage before injection are given in Table 14.

Table 14 : Naga-Hammadi barrage samples before injection.

\begin{tabular}{|c|c|c|c|c|c|c|c|c|c|c|}
\hline No. & Sample & $\underset{\mathbf{m m}}{\mathbf{H}}$ & $\begin{array}{c}\mathrm{D} \\
\mathbf{m m}\end{array}$ & $\begin{array}{l}\text { Vt. } \\
\mathrm{Cm}^{3}\end{array}$ & \begin{tabular}{|c} 
Dry \\
wt gm
\end{tabular} & $\begin{array}{c}\text { Wet } \\
\text { wt gm }\end{array}$ & $\begin{array}{l}\text { Vv. } \\
\text { cm }^{3}\end{array}$ & $\begin{array}{c}n= \\
V v / V t\end{array}$ & e & $\begin{array}{c}(\gamma) \\
\mathbf{g m} / \mathbf{c m}^{3}\end{array}$ \\
\hline 1 & $19-\mathrm{A}$ & 75 & 50 & 147.2 & 351.9 & 371.2 & 19.3 & 0.129 & 0.148 & 2.39 \\
\hline 2 & $4-B$ & 75 & 50 & 147.2 & 340.4 & 364.4 & 24 & 0.163 & 0.195 & 2.31 \\
\hline 3 & 9-A & 75 & 50 & 147.2 & 347.4 & 369.9 & 22.5 & 0.153 & 0.181 & 2.36 \\
\hline 4 & $31-A$ & 75 & 50 & 147.2 & 350.8 & 368.6 & 17.8 & 0.121 & 0.138 & 2.38 \\
\hline 5 & $39-A$ & 75 & 50 & 147.2 & 346.7 & 365.4 & 18.7 & 0.127 & 0.146 & 2.36 \\
\hline 6 & $15-\mathrm{B}$ & 75 & 50 & 147.2 & 350.4 & 367.1 & 16.7 & 0.113 & 0.127 & 2.38 \\
\hline 7 & $40-\mathrm{A}$ & 75 & 50 & 147.2 & 349.1 & 369.1 & 20 & 0.137 & 0.159 & 2.37 \\
\hline 8 & $59-A$ & 75 & 50 & 147.2 & 347.8 & 371.3 & 23.5 & 0.16 & 0.25 & 2.36 \\
\hline 9 & $2-B$ & 75 & 50 & 147.2 & 348.4 & 375.1 & 26.7 & 0.18 & 0.22 & 2.37 \\
\hline \multicolumn{8}{|c|}{ The averas } & 0.143 & 0.174 & 2.36 \\
\hline
\end{tabular}

-After injection:_The void ratio, porosity and density for the samples of NagaHammadi barrage after injection are given in Table 15. 
Table 15: Naga-Hammadi barrage samples after injection.

\begin{tabular}{|c|c|c|c|c|c|c|c|c|c|c|}
\hline No. & Sample & $\begin{array}{c}\mathbf{H} \\
\mathbf{m m}\end{array}$ & $\begin{array}{c}\mathrm{D} \\
\mathbf{m m}\end{array}$ & $\begin{array}{l}\text { Vt. } \\
\mathrm{Cm}^{3}\end{array}$ & $\begin{array}{c}\text { Dry wt } \\
\text { gm }\end{array}$ & $\begin{array}{c}\text { Wet wt } \\
\text { gm }\end{array}$ & $\begin{array}{l}\mathrm{Vv} \text {. } \\
\mathrm{cm}^{3}\end{array}$ & $\begin{array}{c}n= \\
V v / V t\end{array}$ & e & $\begin{array}{c}(\gamma), \\
\mathrm{gm} / \mathrm{cm}^{3}\end{array}$ \\
\hline 1 & $21-\mathrm{A}$ & 75 & 50 & 147.2 & 362.3 & 376.9 & 14.6 & 0.099 & 0.11 & 2.46 \\
\hline 2 & $31-\mathrm{D}$ & 75 & 50 & 147.2 & 373.4 & 385.2 & 12.1 & 0.082 & 0.089 & 2.54 \\
\hline 3 & $35-C$ & 75 & 50 & 147.2 & 387.3 & 394.2 & 6.9 & 0.047 & 0.049 & 2.63 \\
\hline 4 & $37-C$ & 75 & 50 & 147.2 & 380.6 & 398.1 & 17.5 & 0.12 & 0.136 & 2.58 \\
\hline 5 & $15-\mathrm{D}$ & 75 & 50 & 147.2 & 370.5 & 385.6 & 15.1 & 0.10 & 0.11 & 2.52 \\
\hline 6 & $18-\mathrm{A}$ & 75 & 50 & 147.2 & 378.6 & 396.2 & 17.6 & 0.12 & 0.136 & 2.57 \\
\hline 7 & $28-B$ & 75 & 50 & 147.2 & 362.8 & 379.3 & 16.5 & 0.11 & 0.123 & 2.46 \\
\hline 8 & $23-\mathrm{B}$ & 75 & 50 & 147.2 & 402.5 & 408.8 & 6.3 & 0.042 & 0.044 & 2.73 \\
\hline 9 & $10-\mathrm{C}$ & 75 & 50 & 147.2 & 341.5 & 343.2 & 1.7 & 0.011 & 0.01 & 2.93 \\
\hline 10 & 13-B & 75 & 50 & 147.2 & 362.2 & 381.3 & 19.1 & 0.13 & 0.15 & 2.46 \\
\hline \multicolumn{8}{|c|}{$\left.e^{\prime}\right) a n$} & .086 & .0957 & 2.53 \\
\hline
\end{tabular}

The void ratio, porosity and density before injection and after injection for the samples are given in Figs. 16 and 17.

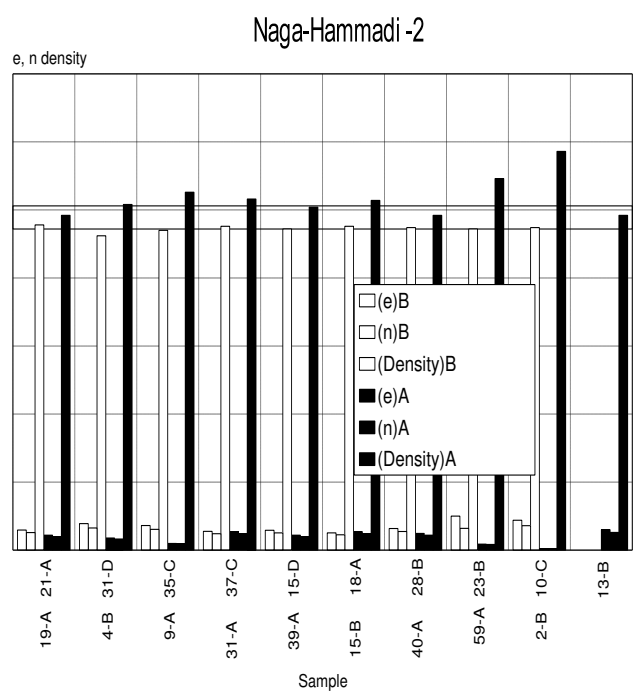

Fig. 16: Void ratio, porosity and density.

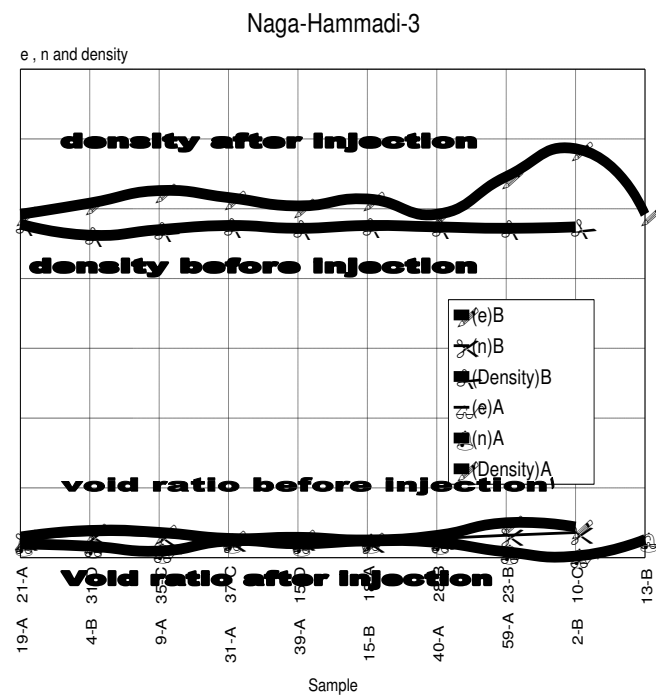

Fig. 17: (e, $\mathrm{n}$ and density) before and after injection.

The results and analysis from tables 14, 15 and figs 16,17 are as follows :

1-The void ratio: The average void ratio after injection $\left.\left(\mathrm{e}^{\prime}\right) \mathrm{A}=0.0957\right)$ was improved compared with the average void ratio for the samples before injection \{the average void ratio for the samples before injection $\left.\left(\mathrm{e}^{\prime}\right) \mathrm{B}=0.174\right\}$.

2-The porosity: The average porosity after injection $\left.\left(\mathrm{n}^{\prime}\right) \mathrm{A}=0.086\right\}$ was improved compared with the average porosity for the samples before injection \{the average porosity for the samples before injection $\left.\left(n^{\prime}\right) B=0.143\right\}$. 
3-The density: The average density $\left.\left(\gamma^{\prime}\right) \mathrm{A}=2.53 \mathrm{gm} / \mathrm{cm}^{3}\right\}$ was improved compared with the average density before injection the average density before injection $\left(\gamma^{\prime}\right) \mathrm{B}=2.36$ $\mathrm{gm} / \mathrm{cm}^{3}$ \}

The improvement $\left(\mathrm{e}^{\prime}\right),\left(\mathrm{n}^{\prime}\right)\left(\gamma^{\prime}\right)$ was $(45 \%),(40 \%)$ and $(7 \%)$ respectively.

\section{CONCLUSIONS AND RECOMMENDATIONS}

The most important conclusions are as follows:

1- The injection way for repairing the structures is very effective way especially for the water structures like Barrages piers constructed from plain concrete with stone (masonry).

2- The injection of concrete piers body is effective on the compressive strength and the increase ranging between $(30.2 \%)$ to $(140.62 \%)$.

3 - The injection of concrete piers body is effective on the density and the density increase by effective value.

4- For successfully injection operation suitable system is required and suitable design program with successive study steps should be made.

5- The results show very clear the effect of injection on the density of the pier body, the density increase by effective value, and the structure body became very dense after injection.

6- The compressive strength for Assiut barrage samples after injection increased by (112.63\%) compared with the average compressive strength of the samples before injection and for Naga-Hammadi barrage the compressive strength increased by $(81.75 \%)$ compared with the average compressive strength of the samples before injection

7- The density for Assiut barrage samples after injection increased by $(8.1 \%)$ compared by the average density before injection and for Naga-Hammadi barrage the density increased by (7\%) compared with the average density before injection.

\section{REFERENCES}

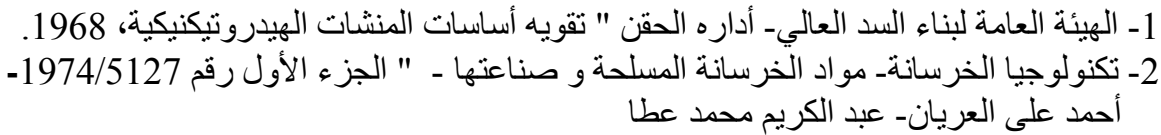

3- "Foundation Engineering Handbook- Injections" C.Caron, Thomas F. Herbst \& P. Cattin.(337-352), 1980.

4- "Geotechnical Investigation-Part1: boring-permeability-grouting" Naga-hammadi barrage, Second stage: Saad El-Khwalka, Sherif H. Soliman and Amin A. Awad (Execution report), 1985.

5- "Strengthening of Assiut barrage- Third stage" Ministry of Water Resources and Irrigation. Grand barrage sector, Cairo. (Execution report), 1987.

6- "Strengthening of Naga-Hammadi barrage-Third stage" Ministry of Water Resources and Irrigation, Grand barrage sector, Cairo (Execution report), 1987.

7- "Crack Repairs to Concrete Pavement" Brock E Hoskins and B. P. McCullough (ACI), (Concrete International) February, (Pages 37-41), 1991.

8- "Crack Repairs to Upper Stillwater Dam" W.Glenn Smoak:,(Concrete International), (Pages 33-36), February 1991. 
9- "Concrete Deck Renews Delaware Aqueduct Bridge" Fu -Kuei Chang and Edward Cohen.(Concrete International), February, 1991 (Pages 27-29)

10- "Tests of Reinforced Concrete Continuous Beams Repaired With and Without Fibro-Ferro Crete" Randall W. Poston, Danlol J. McCarthy and Morris Sohupack:, (Concrete International)-March, 1992.

11- "In-situ Properties of Concrete Piles Repaired Under Water" Kamal Henri Khayat: (Concrete International)-March, 1992.(Pages 42-49)

12- "Grouting Technology in Tunneling and Dam Construction" Arvind V. Shroff \& Dhananjay L .Shah AA. Balkema / Rotterdam / Brookfield, 1993.

13- "Repair \& strengthening of structures using advanced composite materials" Kamal Hassan Proceeding of the first International Civil Engineering "Egypt-ChinaCanada" Symposium Cairo -Egypt 18-20 December ,1997, (Pages 89-99)

14- "Strengthening of Existing Building Elements" M.K.El Samny, H.H.Abbas\& A.M.El sebai: -Proceeding of the first International Civil Engineering "EgyptChina-Canada" Symposium Cairo -Egypt 18-20 December ,1997 (Pages 111-117)

15- "Assessment of the Effectiveness Of Repair Materials to Protect Deteriorated Concrete Structures" Khaled F.Hassan, Joe G. Cabrera \& Syed A. Ahmed : Proceeding of the first International Civil Engineering "Egypt-China-Canada" Symposium Cairo -Egypt 18-20 December ,1997,(Pages 37-42).

16- "Repair and strengthening of reinforced concrete bridge piers for enhanced seismic performance" Yang Xinbao Yuan Wancheng, Fan Lichu : Proceeding of the first International Civil Engineering "Egypt-China-Canada" Symposium Cairo -Egypt 18-20 December, 1997 (Pages 171-176).

17- "Influence of grout proportions on modulus of elasticity of two-stage concrete" H.S Abdelgader and J.Gorski (Technical University of Gdansk, Poland). (Magazine of Concrete Research, 2002, 54 No 4, August , 251-255)

\section{ترميم و تقويه بغال القتاطر المائية عن طريق تقنية الحقن وتقييمها}

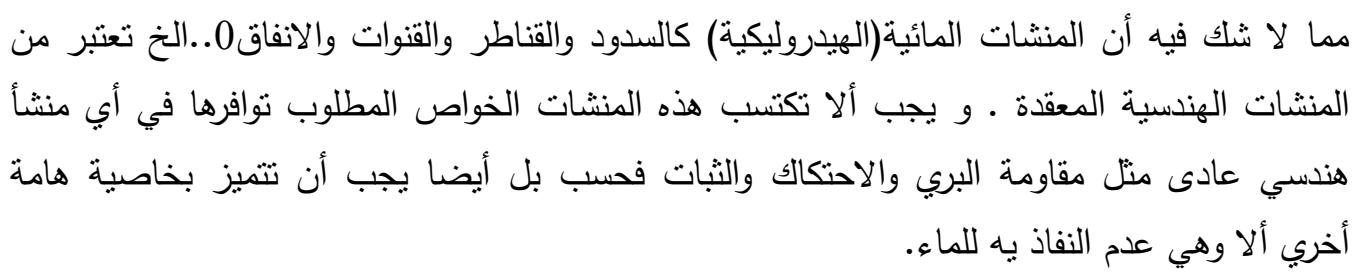
والمنشات المائية الجديدة باهظة التكاليف وتحتاج إلى رصد ميزانيات ضخمه لتنفيذها مما تمثله من

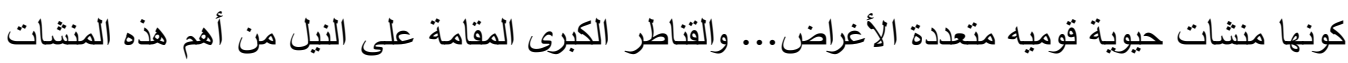

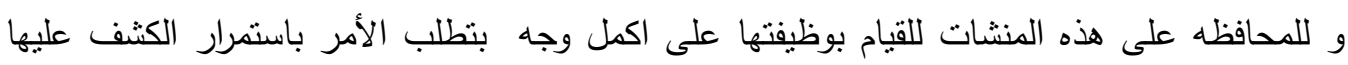
والقيام بتدعيم عناصرها المختلفة.

في هذه الدر اسه سيتم تتاول ترميم وتقويه أحد عناصر هذه المنشات وهو تقويه البغال حتى يمكن الاستفادة منها أطول فتره ممكنة لتعمل بكفاءة عاليه. 
وحيث أن عمليه الحقن تساعد على أعاده مليء الفراغات التي توجد بفعل الزمن أو بفعل مؤثرات مختلفة

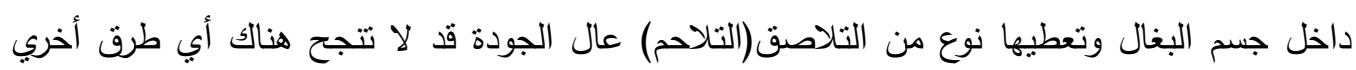
بخلاف عمليه الحقن.

ولهذا قد استخدمت أعمال الحقن بكفاءة عاليه في وزاره الموارد المائية والري و تم تدعيم جميع القناطر

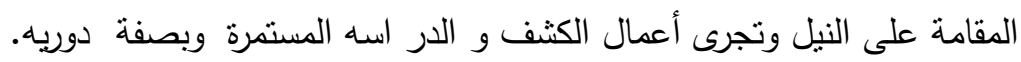
تم الاستعانة بالبيانات و السجلات المصاحبة لاعمال تقويه قناطر أسيوط وكذلك نقويه قناطر نجع

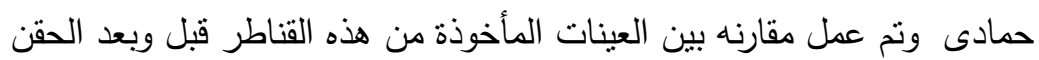

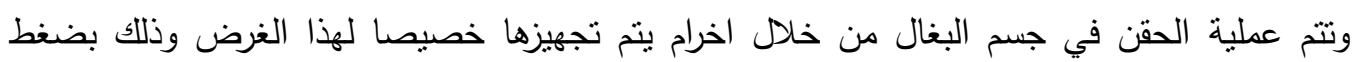
خلطة الأسمنت أو خليط الحقن لتملأ الشروخ والفراغات والفواصل التي قد تتواجد في في جسم البغال. وتتم عملية الحقن من داخل مواسير خاصة مركب بها بلوف الحقن و تتبت هذه المواسير داخل الاخرام

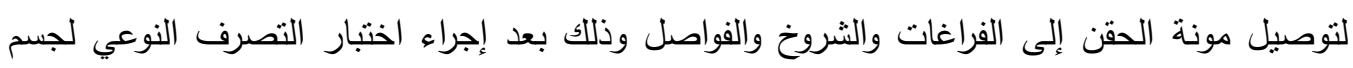
المنشأ لتحديد نسب الخليط (أسمنت: ماء) أو حسب مكونات مادة الحقن. ولقد أعطت نتائج أعمال الحقن نتائج طيبه ومثجعه نؤدى إلى التوسع في أعمال الحقن إذ أظهرت التهرت النتائج الآتي:

- - زادت قيم مقاومة الضغط لعينات بغال المنشأ بنسب عالية (تراوحت بين 30\% والى140\%).

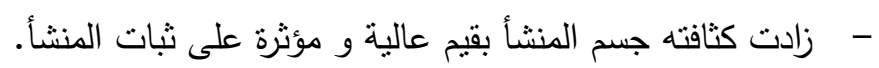

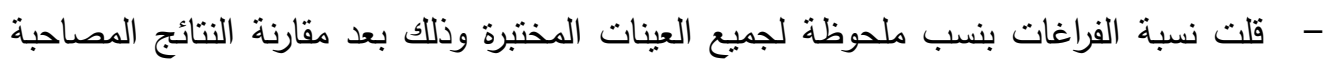
لعينات أخذت للمنشأ قبل وبعد الحقن. 